\title{
PLANTS
}

\section{FLOWERING RUSH, Butomus umbellatus, A NEW, POTENTIALLY INVASIVE, SPECIES IN SASKATCHEWAN}

\author{
RANDY OLSON, 29 Potter Cr., Saskatoon, SK S7H 3L2
}

In the summer of 2003, Etienne Soulodre called the W. P. Fraser Herbarium at the University of Saskatchewan in Saskatoon to report a mystery plant. He had been talking to Allan and Linda Leslie, ranchers east of Young, SK who had noticed a conspicuous pink-flowered plant earlier in the summer in a wetland south of their home (Figure 1). Etienne visited the site and, based on some gardening catalogues that Linda and Allan had, he theorized that the plant might be Flowering Rush (Butomus umbellatus L.).

Etienne brought the plant to my attention when I was working as the curatorial technician at the W. P. Fraser Herbarium, and on September 17, 2003, I visited the site with Linda. Approximate coordinates for the locality are $51.7^{\circ} \mathrm{N}$ and $105.64^{\circ} \mathrm{W}$. We found two $1.5 \mathrm{~m}^{2}$ clumps growing at the edge of the wetland in fine-textured, water-saturated soil. Earlier in the summer, the plants had been seen growing in standing water but the plants were now thoroughly dried out and had set seed. I was able to confirm that the mystery plants were indeed Flowering Rush and collected several specimens, which were submitted to the W. P. Fraser Herbarium

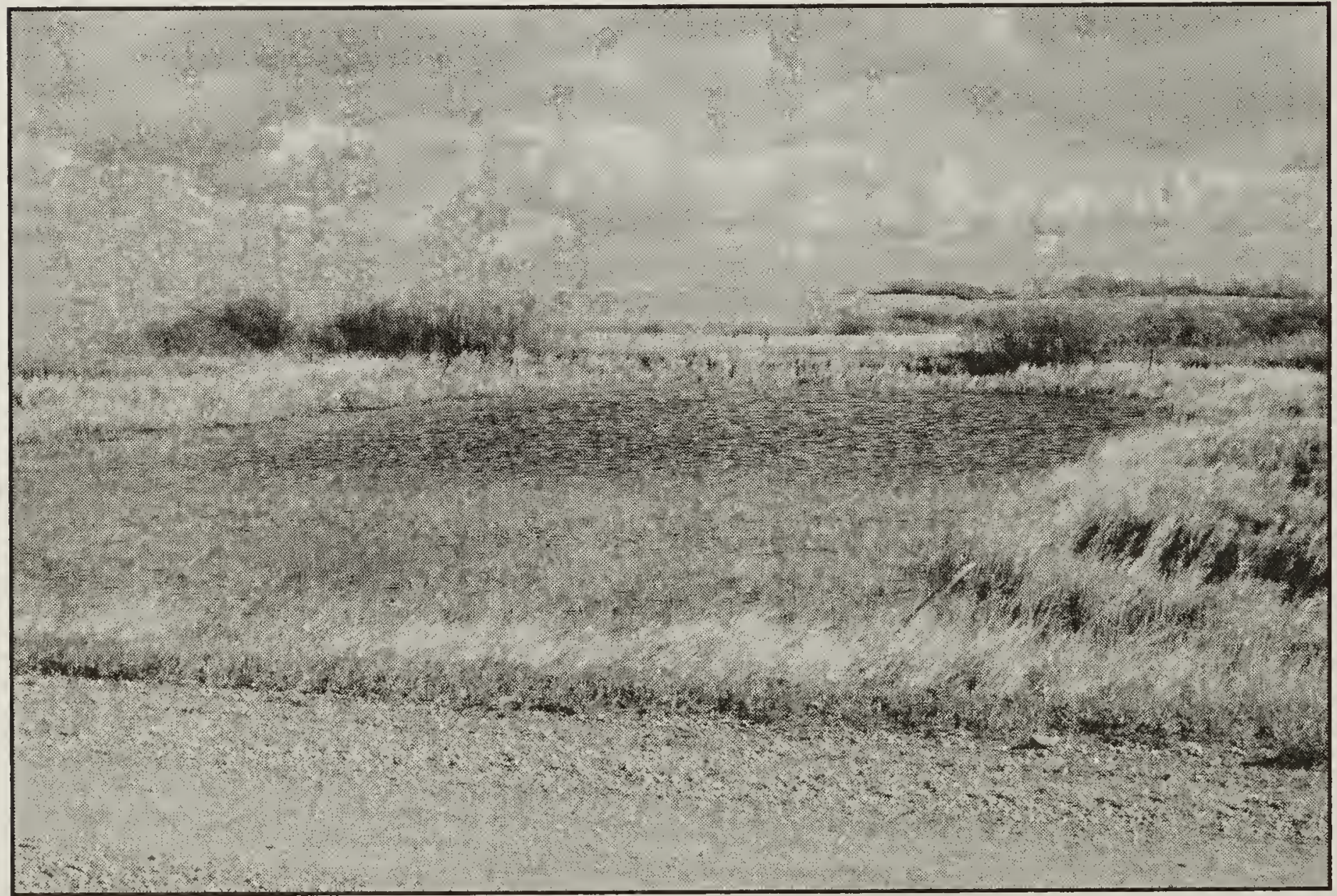


(SASK) as collection number BU RO\#1.

Associated species were Silverweed Cinquefoil (Argentina anserina (L.) Rydb.), Smooth Brome (Bromus inermis Leyss.), Water Sedge (Carex cf. aquatilis Wahl.), Spotted Water Hemlock (Cicuta maculata L.), Fringed Willowherb (Epilobium ciliatum Raf.), Baltic Rush (Juncus balticus Willd.), Alfalfa (Medicago sativa L.), Common Reed (Phragmites australis (Cav.) Trin. \& Steud.), Dock (Rumex sp.), Ragwort (Senecio sp.), Broadleaf Cattail (Typha latifolia L.) and poorly developed mosses. Mallards were also seen swimming nearby.

Flowering Rush is the only species in the family Butomaceae. ${ }^{4}$ It is especially easy to

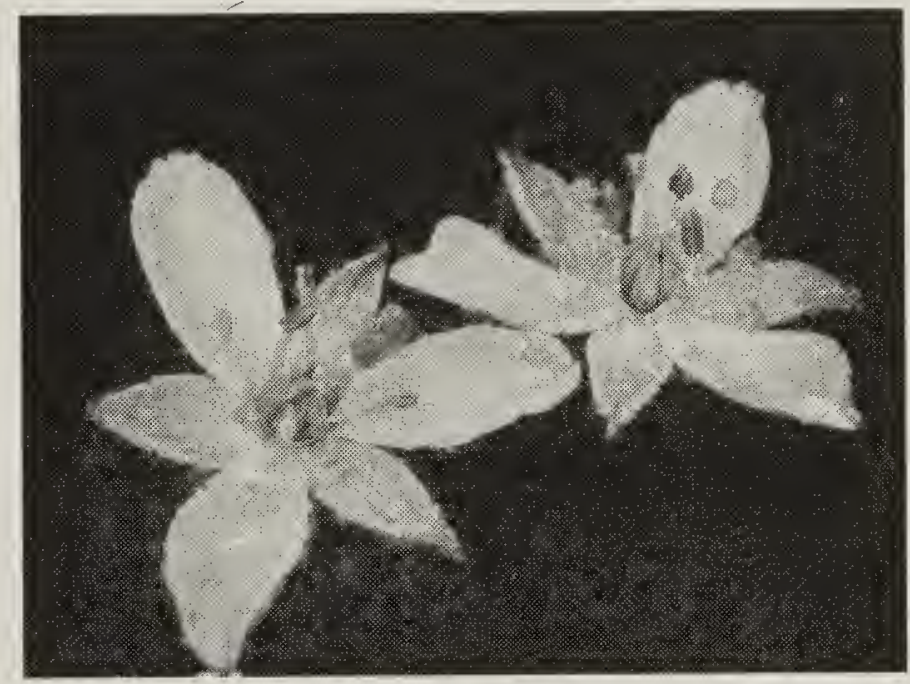

Figure 2. The flowers of Flowering Rush (non-Saskatchewan specimen)

Chris Eckert

recognize when flowering (Fig. 2). Each flower has three pink petals and three pink sepals. The petals and sepals are poorly differentiated, with the sepals being slightly smaller than the petals and occasionally with a greenish tinge. The flowers have nine stamens and six pistils. ${ }^{4}$ The plant grows in large clumps from rhizomes (Fig. 3). The umbels of large flowers (about 2-2.5 cm wide) are produced on upright, leafless stems. The basal leaves are 2-ranked, up to $1 \mathrm{~cm}$ wide, usually about $1 \mathrm{~m}$ long (up to 2.7 $\mathrm{m}$ ) and triangular in cross section., 13 The flowers mature into small dark, many-seeded follicles with long beaks (Figs. 4 \&. 5). Flowering Rush reportedly flowers from June to August and is typically found in wetlands, growing in water up to $2 \mathrm{~m}$ deep although it can also be found growing completely underwater., 6

Native to Europe and temperate Asia, Flowering Rush was first recorded in North America in 1897 near Montreal. 1, 10, 12 Flowering Rush has since spread to the northern United States and within Canada. ${ }^{4}$

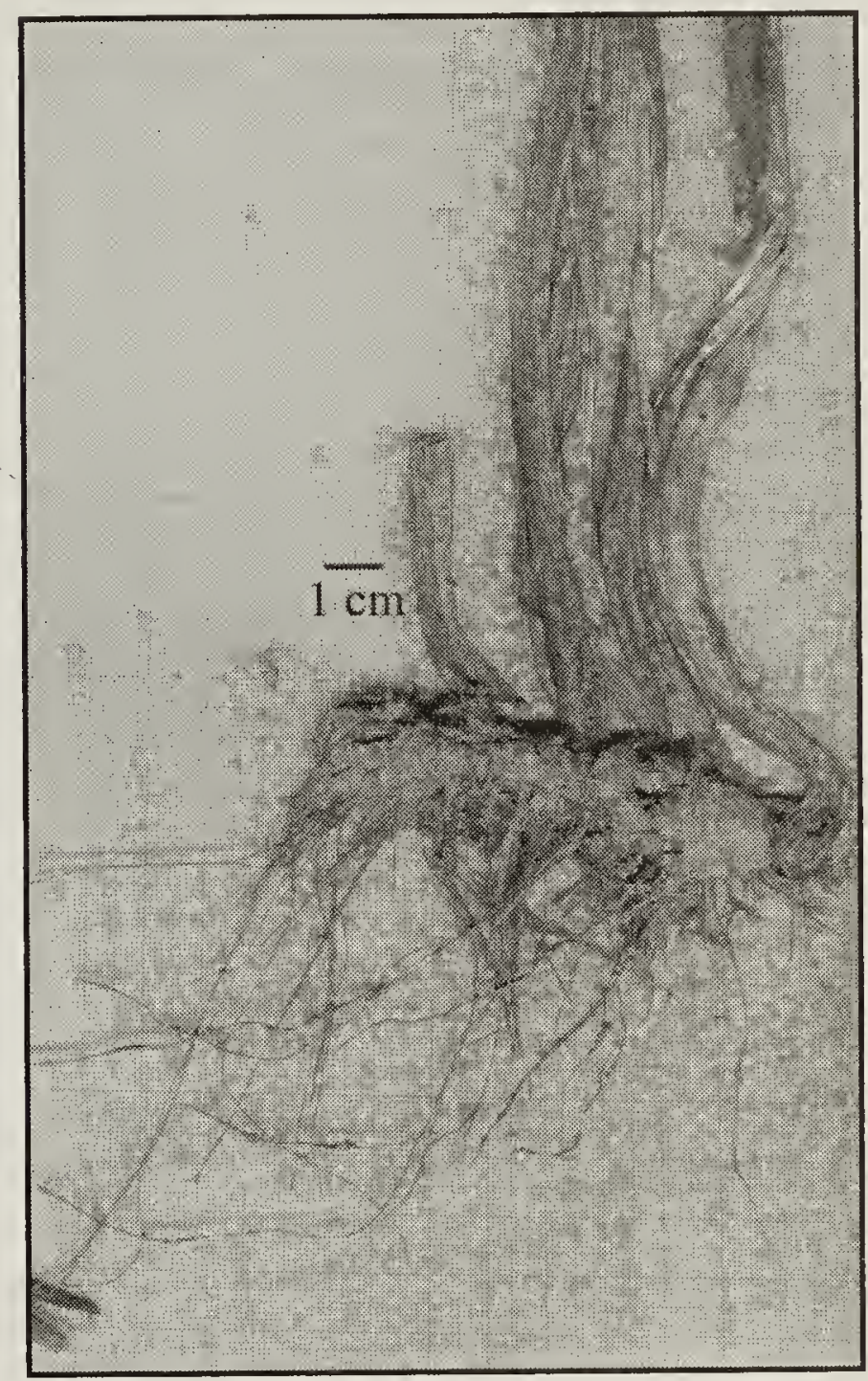

Figure 3. The rhizome and bottom part of the leaves of Flowering Rush Randy olson

In Canada, Flowering Rush is most widespread in the east. ${ }^{15}$ Sporadic populations have been found in the western provinces, including Alberta and Manitoba. ${ }^{14,}$ 15

How the first Saskatchewan population was introduced is unknown. Flowering Rush is widely sold as an ornamental for planting in small-scale ponds, and may have escaped from cultivation. Some authors have speculated that long-range dispersal may 


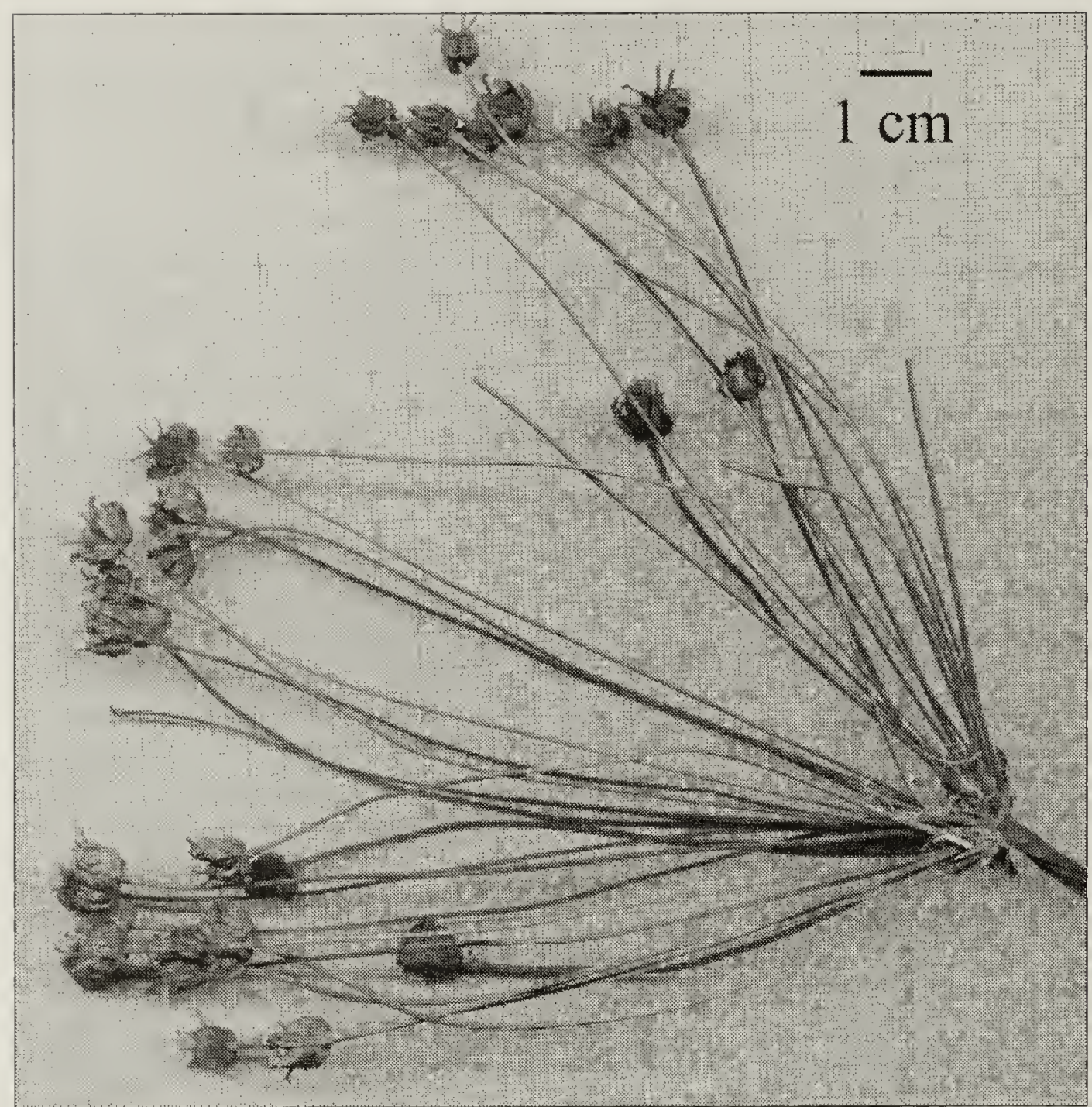

Figure 4. The umbel of Flowering Rush

Purple Loosestrife ( Lythrum salicaria L.). ${ }^{7}$ However, the biology of Flowering Rush and impact on native ecosystems have yet to be fully explored and there are some indications that the threat posed by Flowering Rush has been underestimated previously. $^{2}$

Populations of Flowering Rush tend to be either diploid or triploid. Triploids rarely $\mathrm{p}$ r o d u c e inflorescences or bulbils; they rely instead on highly

occur via waterfowl. ${ }^{14}$ Once established, Flowering Rush has been known to spread by rhizome fragmentation and through vegetative bulbils on the inflorescence and rhizomes. ${ }^{2,8,14}$ This species also produces many seeds, which remain viable for at least 5 years. ${ }^{2,11}$ This wide range of reproductive methods appears to be a major part of this plant's ecological success. ${ }^{2}$

In northeastern North America, Flowering Rush is of major concern as an invasive weed and is being recognized as a potentially invasive species in other parts of the continent. ${ }^{14}, 15$ Flowering Rush has been shown to be intolerant, but not completely so, to establishment in saline and brackish water. ${ }^{5.12}$ In the Prairie Provinces, Flowering Rush is expected to mainly threaten fresh water marshes. ${ }^{15}$ The current threat of Flowering Rush to the prairies is fairly moderate in comparison to other species like
Randy Olson branched rhizomes for reproduction. ${ }^{9}$ Diploid populations present the greatest invasive threat when introduced into a new region because they produce many, highly viable seeds and bulbils. ${ }^{2,9}$ Interestingly, the bulbils apparently out-compete seeds for suitable sites for establishment as few plants growing from seed reach maturity. ${ }^{3}$ Populations found well outside the normal range of Flowering Rush are usually triploids escaped from cultivation. ${ }^{9}$ Examination of the material collected near Young revealed no bulbils on the rhizomes or inflorescences. Based on this, the population found near Young is likely an escaped triploid. However, ploidy levels from these plants have not been confirmed.

Many new populations of Flowering Rush appear to be the result of human introductions. ${ }^{15}$ Early detection and monitoring of invasive species is crucial to 


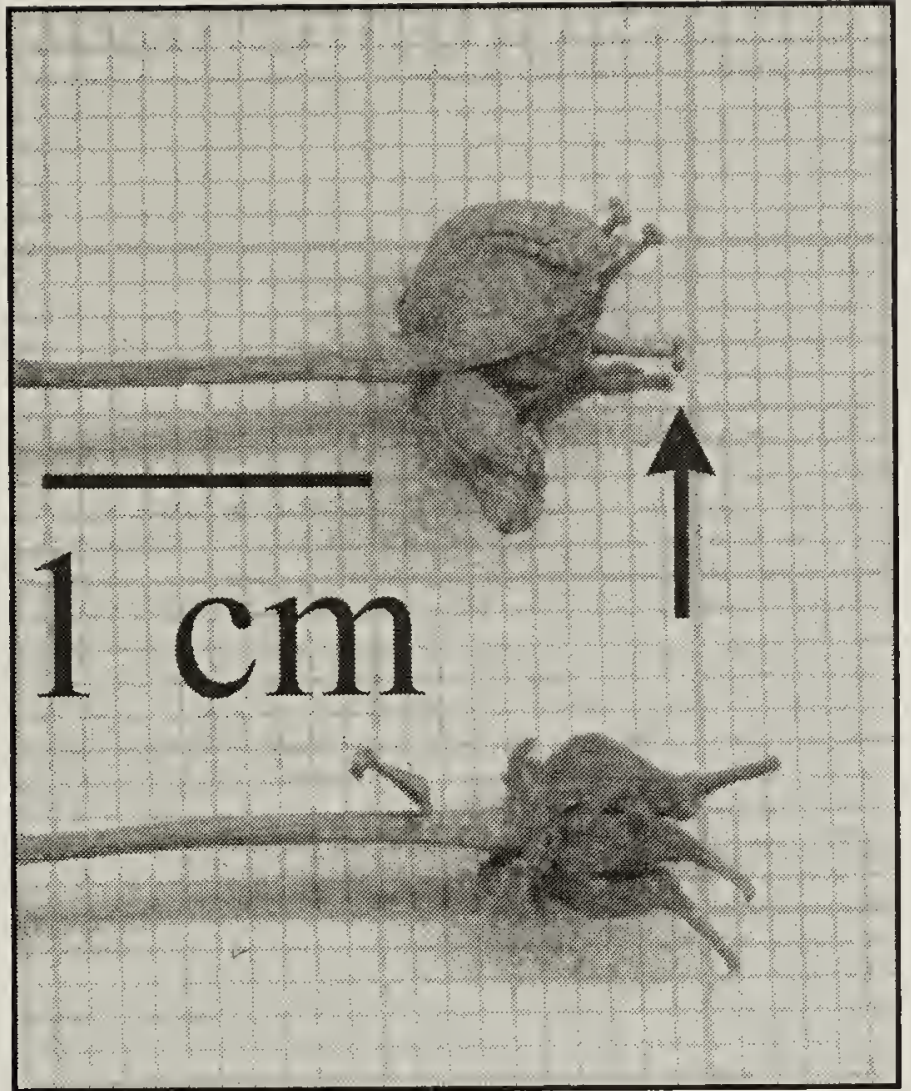

The fruits of Flowering Rush. The arrow points to one of the beaks of the follicles. Randy Olson

ensuring that plant species do not become weeds that threaten native habitat. If you do see this plant, record its exact location and plant features, and report it to: The Saskatchewan Purple Loosestrife \& Invasive Species Project (SPLISP) at 975-4101 (Saskatoon) or 1-877-281-3006.

For more information on Flowering Rush and other invasive species that threaten Saskatchewan go to http:// www.sfn.saskatoon.sk.ca/science/splep/.

\section{Acknowledgements}

I would like to thank Allan and Linda Leslie for their cooperation and help. I would also like to thank Angela Salzl for her assistance in reviewing this article, Dr. Chris Eckert for advice and Figure 2, and Etienne Soulodre, whose report of this population made its early detection possible.

1. ANDERSON, L.C., C.D. ZEIS and S.F. ALAM. 1974. Phytogeography and possible origins of Butomus in North America. Bulletin of the Torrey Botanical Club 101: 292-296.
2. ECKERT, C. G., B. MASSONNET and J. J. THOMAS. 2000. Variation in sexual and clonal reproduction among introduced populations of flowering rush, Butomus umbellatus (Butomaceae). Canadian Journal of Botany 78: 437-446.

3. ECKERT, C.G., K. LUI, K. BRONSON, P. CORRADINI and A. BRUNEAU. 2003. Population genetic consequences of extreme variation in sexual and clonal reproduction in an aquatic plant. Molecular Ecology 12: 331-344.

4. FLORA OF NORTH AMERICA EDITORIAL COMMITTEE, eds. 2000. Flora of North America North of Mexico. Volume 22. Web Site: http:// flora.huh. harvard.edu: $8080 / \mathrm{flora} /$ browse.do?flora_id=1\&taxon_id=10135

Accessed March 2004.

5. GAULTHIER, R. 1972. Le Butomus umbellatus L. en Gaspésie. Naturaliste Canadien 99: 233-235.

6. GREAT PLAINS FLORA ASSOCIATION. 1986. Flora of the Great Plains. University Press of Kansas, Lawrence, Kansas.

7. INVASIVE PLANTS OF NATURAL HABITATS IN CANADA Web Site: Www.cws-scf.ec.gc.ca/ publications/inv/p3_e.cfm Accessed March 2004.

8. LOHAMMER, G. 1954. Bulbils in the inflorescences of Butomus umbellatus. Svensk Botanisk Tidskrift 48: $485-488$.

9. LUI, K., F.L. THOMPSON and C.G. ECKERT. Causes and consequences of extreme variation in reproductive strategy among invasive populations of a clonal aquatic plant, Butomus umbellatus (Butomaceae). Unpublished manuscript.

10. MARIE-VICTORIN, F. 1938. Phytogeographical problems of Eastern Canada. The American Midland Naturalist 19: 489-558.

11. MUENSCHER, W. C. 1944. Aquatic Plants of the United States. Cornell University Press, Ithaca and London.

12. ROUSSEAU, C. 1968. Histoire, habitat et distribution de 220 plantes introduites au Québec. Naturaliste Canadien 95: 49-169.

13. SCOGGAN, H. J. 1978. The Flora of Canada: Volume II. National Museums of Canada Publications in Botany, Number 7, Ottawa.

14. SCOTTER, G.W. 1991. Flowering rush, Butomus umbellatus, a new record for Alberta. The Canadian Field-Naturalist 105: 387-389.

15. STANIFORTH, R. J. and K. A. FREGO. 1980. Flowering Rush (Butomus umbellatus) in the Canadian prairies. The Canadian Field-Naturalist 94 : 333-336. 